(c) American Dairy Science Association, 2005.

\title{
Rate of Maillard Browning in Sweet Whey Powder
}

\author{
R. Sithole, M. R. McDaniel, and L. Meunier Goddik \\ Department of Food Science and Technology, Oregon State University, Corvallis 97331
}

\begin{abstract}
The objective of this study was to evaluate the rate of Maillard browning in 3 commercial sweet whey powders (WC1, WC2, and MW1), under accelerated shelflife testing (ASLT) and under normal storage conditions $\left(21^{\circ} \mathrm{C}\right.$ and $\left.35 \% \mathrm{RH}\right)$. Rate of brown pigment formation (k) obtained from short-term ASLT of whey powder was compared with actual findings obtained from the long-term shelf-life testing under normal conditions. Deterioration by Maillard browning, measured by spectrophotometer, was compared with changes in color (Hunter Laboratory), free moisture, titratable acidity, and sensory attributes. Results suggest that estimated $\mathrm{k}$ (from ASLT) was comparable with the observed rate (obtained at ambient temperature) for 2 producers (WC1, MW1). The actual k values observed for samples WC1, WC2, and MW1, stored under normal conditions, were $0.0031,0.0080$, and 0.0148 color units/g of solid per mo, respectively. The estimated values of $\mathrm{k}$ for samples WC1, WC2, and MW1 were 1.12, 4.90, and 1.35 times more than the observed values, respectively. The $\mathrm{Q}_{10}$ values (increase in reaction rate for a $10^{\circ} \mathrm{C}$ temperature increase) ranged from 1.77 to 4.14 , and the activation energies ranged from 15.9 to $28.4 \mathrm{kcal} / \mathrm{mol}$. Hunter Laboratory values $\mathrm{L}^{*}$ and $\mathrm{a}^{*}$ appeared most sensitive to changes during storage. Free moisture content, and acidity increased significantly with storage. However, no significant changes were detected by the sensory panel in the attributes considered.
\end{abstract}

(Key words: Cheddar whey powder, storage stability, Maillard browning, accelerated shelf-life testing)

Abbreviation key: $\mathbf{a}^{*}=$ Hunter Lab red-green parameter, ASLT $=$ accelerated shelf-life testing, $\mathbf{b}^{*}=$ Hunter Lab blue-yellow parameter, $\mathbf{E}_{\mathbf{a}}=$ energy of activation, $\mathbf{k}=$ rate constant, $\mathbf{L}^{*}=$ Hunter Lab lightness-darkness parameter, $\mathbf{M W}=$ Midwest processor, $\mathbf{W C}=$ West coast processor.

Received October 25, 2004.

Accepted December 28, 2004.

Corresponding author: L. Meunier Goddik; e-mail: Lisbeth.goddik @oregonstate.edu.

\section{INTRODUCTION}

Nonenzymatic browning via the Maillard reaction is an important mode of deterioration in dried milk and whey powders, which limits shelf life (Saltmarch and Labuza, 1980). Whey powders contain relatively high concentrations of lactose (approximately 73\%) and protein (approximately 12\%) high in lysine content. In the presence of moisture, these components readily participate in Maillard reactions. The Maillard reaction is affected by the concentration of the initial reactant species, $\mathrm{pH}$, water content, and presence of substances such as humectants and bisulfite (Franzen et al., 1990). Some physical factors, such as processing and storage temperature, atmospheric oxygen, and packaging during storage can also affect the Maillard reaction in foods. The deleterious effects of nonenzymatic browning include: decreased nutritional value from protein loss, off-flavor development, undesirable color, decreased solubility, texture changes, destruction of vitamins, and increased acidity (Saltmarch and Labuza, 1981; Ford et al., 1983; Villota and Hawkes, 1983).

Brown pigment formation has been used as an indicator of the Maillard reaction in food (Waletzko and Labuza, 1976; Saltmarch and Labuza, 1981). Franzen et al. (1990) confirmed that the Maillard reaction is described by zero-order reaction in the sense that the concentration of the brown pigments is negligible compared with the concentration of reactants present. Optimum conditions for the Maillard reaction in whey powders as determined by brown pigment formation have been studied (Choi et al., 1949; Labuza and Saltmarch, 1981).

In their method development for accelerated shelf life testing (ASLT) of whey powder, Labuza and Saltmarch (1981) stored samples in an open system. However, Kim et al. (1981) investigated the effects of storing the samples in open vs. sealed pouches. They observed that the nonenzymatic browning reaction is greatly increased in closed samples compared with samples stored open to the environment, and cautioned that care be taken in using data from ASLT to predict kinetics of deteriorative reactions during shelf-life tests of sealed food systems.

The purpose of this work was to use sealed containers to estimate the rate of deterioration of 3 commer- 
cial whey powders under accelerated storage conditions through the use of the Arrhenius equation with extrapolation. The ASLT data were compared with Maillard browning occurring under normal storage conditions $\left(21^{\circ} \mathrm{C}, 35 \% \mathrm{RH}\right)$. The rate of deterioration by browning of the 3 commercial Cheddar cheese whey powder samples was compared with changes in microbiological, physicochemical, and sensory quality during storage to establish the keeping quality of the whey powders and to validate the use of Maillard browning in determining shelf life.

\section{MATERIALS AND METHODS}

\section{Storage Conditions for Control}

Twelve bags from the same lot of whey powder from 2 West coast processors and 1 Midwest processor (WC1, WC2, and $\mathrm{MW} 1$ ), were stored at $21^{\circ} \mathrm{C}$ and $35 \%$ $\mathrm{RH}$. Samples were withdrawn for analysis after storage for 1, 5, 9, 12, and 19 mo. The storage times were chosen based on the study by Presa-Owens et al. (1995). Samples for sensory analyses were packed in 1-L amber glass bottles supplied with polytetrafluoroethylene-sealed screw caps and stored at $-37^{\circ} \mathrm{C}$ until analysis.

\section{High Temperature Storage}

Four incubators were maintained at $35,45,50$, and $55^{\circ} \mathrm{C}$. Whey powders from WC1, WC2, and MW1 were each packaged into $100-\mathrm{mL}$ glass bottles and equilibrated to 0.44 water activity $\left(\mathrm{a}_{\mathrm{w}}\right)$ according to the method outlined by Labuza and Saltmarch (1981). The bottles were then sealed with polytetrafluoroethylenesealed screw caps. This impermeable system enabled Maillard reaction in high-temperature/low-humidity cabinets without moisture loss. Five to 6 bottled whey powder samples from each processor were incubated at each temperature. Samples were withdrawn from the incubators after the specified storage period and immediately stored at $-37^{\circ} \mathrm{C}$. Samples stored at $35^{\circ} \mathrm{C}$ were withdrawn after $7,19,40,64,91$, and $174 \mathrm{~d}$ of storage. Samples stored at $45^{\circ} \mathrm{C}$ were withdrawn after $9,19,26,60$, and $96 \mathrm{~d}$ of storage. Samples stored at $50^{\circ} \mathrm{C}$ were withdrawn after $11,20,24,37$, and $46 \mathrm{~d}$ of storage, and samples stored at $55^{\circ} \mathrm{C}$ were withdrawn after $5,10,17,20$, and $21 \mathrm{~d}$ of storage.

\section{Evaluation of Brown Pigment Formation}

Brown pigment formation was analyzed by the modified method for milk powders of Choi et al. (1949) as outlined by Labuza and Saltmarch (1981). Chymotrypsin type II from bovine (C4129-1G), trypsin (type
IX-5 T0303-1G), and peptidase from porcine intestinal mucosa (P7500-10UN) were purchased from Sigma (St. Louis, MO). Absorbance was measured at $420 \mathrm{~nm}$ (Cämmerer et al., 1999) (Bio Spec - 1601 DNA/Protein Analyzer cat. \# 206-67001-92, Shimadzu, Kyoto, Japan).

\section{Analytical Methods}

The solubility index was determined by centrifugation according to A/S Niro atomizer (1978), using a Beckman model TJ-6 centrifuge (Beckman, Palo Alto, CA). Titratable acidity as percentage lactic acid and $\mathrm{pH}$ were determined according to the methods outlined by the American Dairy Products Institute (1991). The $\mathrm{pH}$ was measured using a $\mathrm{pH}$ meter (Accumet Research AR25 dual Channel pH/Lon Meter, Fisher Scientific, Fairlawn, NJ) on a 6.5-g whey powder sample in $100 \mathrm{~mL}$ of distilled water. Duplicate analyses were carried out for all analyses.

Color measurements were determined according to the Hunter Laboratory method of measuring loose powder (Nielsen et al., 1997). Analysis was by the tristimulus reflectance colorimeter, Hunter Laboratory CT 1100 Color Quest (SNC49038; Hunter Associates Laboratory Inc., Reston, VA). The operating conditions were: illuminant $\mathrm{C}, 10^{\circ}$ observer value, and reflectance mode and $45 / 0$ sensor. The CIE LAB values $\mathrm{L}^{*}, \mathrm{a}^{*}$, and $\mathrm{b}^{*}$ were measured, with analyses performed in triplicate.

Fat content was determined by the Mojonnier method (AOAC, 2000; method no. 989.05), and protein content determined by the Kjeldahl method (AOAC, 2000; method no. 930.29, 991.20). Calcium was determined by atomic absorption spectrophotometry (AOAC, 2000; method no. 985.35), and lactose was determined using an enzymatic method (AOAC, 1995; method no. 984.15). Salt was determined by indirect Volhart method (AOAC, 2000; method no. 935.43), and scorched particles were analyzed according to the method outlined by the American Dairy Products Institute (1991). Free moisture was determined by oven drying according to the standard methods for the examination of dairy products (Richardson, 1985). Sulfite was quantified and reported as sulfur dioxide (AOAC, 1985; method no. 20:123-125). Duplicate analyses were carried out for all analyses.

\section{Sensory Evaluation}

Prospective panelists were screened for their ability to recognize and rate the intensity of the 4 basic tastes (salty, sour, sweet, and bitter). Odor perception and descriptive identification were assessed by having the 
Table 1. Descriptors, description terms, and preparation of the reference materials for descriptive sensory evaluation of whey powder (adopted from Karagül-Yüceer et al., 2001).

\begin{tabular}{|c|c|c|}
\hline Descriptor & Reference & Description and preparation \\
\hline Cooked aroma and flavor & Heated skim milk & $\begin{array}{l}\text { Aroma and flavor associated } \\
\text { with cooked milk; slightly } \\
\text { sulfuric aroma/taste acquired by } \\
\text { a product that has been } \\
\text { submitted to heat treatment; } \\
\text { pasteurized skim milk heated to } \\
85^{\circ} \mathrm{C} \text { for } 55^{*} \text { min. }\end{array}$ \\
\hline Caramelized aroma and flavor & Autoclaved skim milk & $\begin{array}{l}\text { Milk autoclaved at } 121^{\circ} \mathrm{C} \text { for } 30 \\
\text { min; taste suggestive of soft } \\
\text { caramel due to Maillard reaction. } \\
\text { This characteristic goes with the } \\
\text { series biscuit, caramel, and } \\
\text { burnt. }\end{array}$ \\
\hline $\begin{array}{l}\text { Sweet aromatic/cake mix aroma } \\
\text { and flavor }\end{array}$ & $\begin{array}{l}\text { Pillsbury Moist Supreme classic white } \\
\text { premium cake mix }\end{array}$ & $\begin{array}{l}\text { Aroma and flavor associated } \\
\text { with diacetyl. }\end{array}$ \\
\hline Barny/animal-like aroma and flavor & p-cresol (C7525, Sigma) & $10^{*}$ ppm in skim milk. \\
\hline Oxidized aroma and flavor & (E,E)-2,4-decadienal (12117CB, Aldrich) & $\begin{array}{l}\text { Aroma/flavor associated with } \\
\text { old oil, metallic, paint; } 2 \text { ppb in } \\
\text { skim milk. }\end{array}$ \\
\hline Papery/cardboard aroma & Cardboard & $\begin{array}{l}\text { Aroma associated with } \\
\text { cardboard; sensation provoked } \\
\text { by defective packaging or by a } \\
\text { slight oxidation of product; } \\
\text { pieces of cardboard paper ( } 3 \% \\
\text { wt/vol) soaked in skim milk overnight. }\end{array}$ \\
\hline Sweet & Sucrose & $\begin{array}{l}\text { Basic taste associated with } \\
\text { sucrose; } 1 \% * \text { wt/vol sucrose } \\
\text { solution. }\end{array}$ \\
\hline Salty & $\mathrm{NaCl}$ & $\begin{array}{l}\text { Basic taste associated with salt; } \\
0.2 \% * \mathrm{wt} / \mathrm{vol} \mathrm{NaCl} \text { solution. }\end{array}$ \\
\hline Sour & Citric acid & $\begin{array}{l}\text { Basic taste associated with acid; } \\
0.05 \% * \text { wt/vol citric acid } \\
\text { solution. }\end{array}$ \\
\hline
\end{tabular}

\footnotetext{
*Signify standards modified from Karagül-Yüceer, 2001.
}

panelists take short sniffs of the attributes cooked, caramelized, and barny via duplicated triangle tests. Results of acuity and rating tests were used to make the final selection of 13 panelists (12 women and 1 man).

Training was carried out during nineteen 1 -h sessions. A modified Spectrum method (Lawless and Heymann, 1999) was used because it uses scientific terms, which relate to product composition, production, and development, rather than consumer terms, making it easier to relate to the science behind the product. The Quantitative Descriptive method (Stone and Sidel, 1993) was used. (Panelists created the preliminary lexicon after tasting the whole range of whey powders. Additional descriptors and standards were adopted from Karagül-Yüceer et al. (2001). Descriptors used are shown in Table 1. Testing was a complete randomized block design with three coded samples presented

Table 2. Proximate composition ${ }^{1}$ with separation of means of commercial Cheddar whey powder samples from processors from the West coast (WC1 and WC2) and the Midwest (MW1).

\begin{tabular}{lllllllll}
\hline Processor & $\begin{array}{l}\text { Salt } \\
(\%)\end{array}$ & $\begin{array}{l}\text { Calcium } \\
(\%)\end{array}$ & $\begin{array}{l}\text { Protein } \\
(\%)\end{array}$ & $\begin{array}{l}\text { Free moisture } \\
(\%)\end{array}$ & $\begin{array}{l}\text { Fat } \\
(\%)\end{array}$ & $\begin{array}{l}\text { Lactose } \\
(\%)\end{array}$ & $\mathrm{pH}$ & $\begin{array}{l}\text { Sulfite } \\
(\mathrm{ppm})\end{array}$ \\
\hline WC1 & $2.197^{\mathrm{a}}$ & $488.0^{\mathrm{b}}$ & $12.8967^{\mathrm{b}}$ & $1.2967^{\mathrm{a}}$ & $1.2300^{\mathrm{a}}$ & $71.0^{\mathrm{a}}$ & $6.1533^{\mathrm{a}}$ & $\mathrm{ND}^{2}$ \\
WC2 & $2.187^{\mathrm{a}}$ & $5597^{\mathrm{c}}$ & $11.8700^{\mathrm{a}}$ & $1.6000^{\mathrm{b}}$ & $1.2367^{\mathrm{a}}$ & $722^{\mathrm{a}}$ & $6.2900^{\mathrm{a}}$ & $\mathrm{ND}^{\mathrm{a}}$ \\
MW1 & $2.530^{\mathrm{b}}$ & $403.7^{\mathrm{a}}$ & $12.6800^{\mathrm{b}}$ & $1.5967^{\mathrm{b}}$ & $1.6067^{\mathrm{b}}$ & $71.8^{\mathrm{a}}$ & $6.2667^{\mathrm{a}}$ & $\mathrm{ND}$ \\
\hline
\end{tabular}

${ }^{\mathrm{a}-\mathrm{c}}$ Means within columns with different letters are statistically different $(P<0.05)$.

${ }^{1}$ Means from triplicate analysis of composite sample.

${ }^{2} \mathrm{ND}=$ Not detected. 
Table 3. Equations and $R^{2}$ values for the Arrhenius plots (log k vs. 1/K) and the plots of color units/g of solid vs. storage time.

\begin{tabular}{llll}
\hline Storage temperature $\left({ }^{\circ} \mathrm{C}\right)$ & Processor $^{1}$ & Equation & $\mathrm{R}^{2}$ \\
\hline 35 & WC1 & $\mathrm{y}=0.0006 \mathrm{x}+0.3076$ & 0.8247 \\
45 & WC1 & $\mathrm{y}=0.0018 \mathrm{x}+0.2447$ & 0.9327 \\
50 & WC1 & $\mathrm{y}=0.0057 \mathrm{x}+0.2129$ & 0.8647 \\
21 & WC1 & $\mathrm{y}=0.0031 \mathrm{x}+0.1592$ & 0.9395 \\
35 & WC2 & $\mathrm{y}=0.0034 \mathrm{x}+0.3181$ & 0.9831 \\
50 & WC2 & $\mathrm{y}=0.0073 \mathrm{x}+0.3829$ & 0.9803 \\
55 & WC2 & $\mathrm{y}=0.0199 \mathrm{x}+0.2387$ & 0.8811 \\
21 & WC2 & $\mathrm{y}=0.0084 \mathrm{x}+0.2895$ & 0.8431 \\
35 & MW1 & $\mathrm{y}=0.0028 \mathrm{x}+0.3046$ & 0.9945 \\
45 & MW1 & $\mathrm{y}=0.0116 \mathrm{x}+0.2007$ & 0.988 \\
50 & MW1 & $\mathrm{y}=0.00204 \mathrm{x}+0.2772$ & 0.8923 \\
21 & MW1 & $\mathrm{y}=0.0148 \mathrm{x}+0.118$ & 1.000 \\
Arrhenius plot & WC1 & $\mathrm{y}=6206.4 \mathrm{x}-16.891$ & 0.9542 \\
Arrhenius plot & WC2 & $\mathrm{y}=3468.3 \mathrm{x}-8.7555$ & 0.8684 \\
Arrhenius plot & MW1 & $\mathrm{y}=5770.2 \mathrm{x}-16.188$ & 0.9982 \\
\hline
\end{tabular}

${ }^{1} \mathrm{WC}=$ Processors from West coast; MW = processor from Midwest.

to the panelist at one time. Panelists constituted a block.

For aroma and flavor evaluation, $10 \mathrm{~g}$ of whey powder and $0.01 \mathrm{~mL}$ of color (McCormick red food color to prevent the appearance of whey from influencing a panelist's decision) were suspended in $100 \mathrm{~mL}$ of spring water at $40^{\circ} \mathrm{C}$ and mixed by electric mixer at $200 \mathrm{rpm}$ for $2 \mathrm{~min}$. Samples $(70 \mathrm{~mL}$ ) were served in clear wine glasses covered with plastic lids, and were evaluated at $25 \pm 2^{\circ} \mathrm{C}$ after standing for $2 \mathrm{~h}$ (Kamath et al., 1999) to allow for release of volatile aroma into the head space. After evaluation of aroma, flavor was evaluated. Each panelist judged each sample twice.

\section{Microbiological Analysis}

The microbiological analyses carried out on the whey sample were standard plate count, mesophilic and psychrophilic spores, coliform bacteria, and yeast and molds. All methods used were from the American Dairy Products Institute (1991). The microbiological media were supplied by VWR International (West Chester, PA).

\section{Statistics}

Multivariate and univariate ANOVA were performed. For the compositional and microbiological

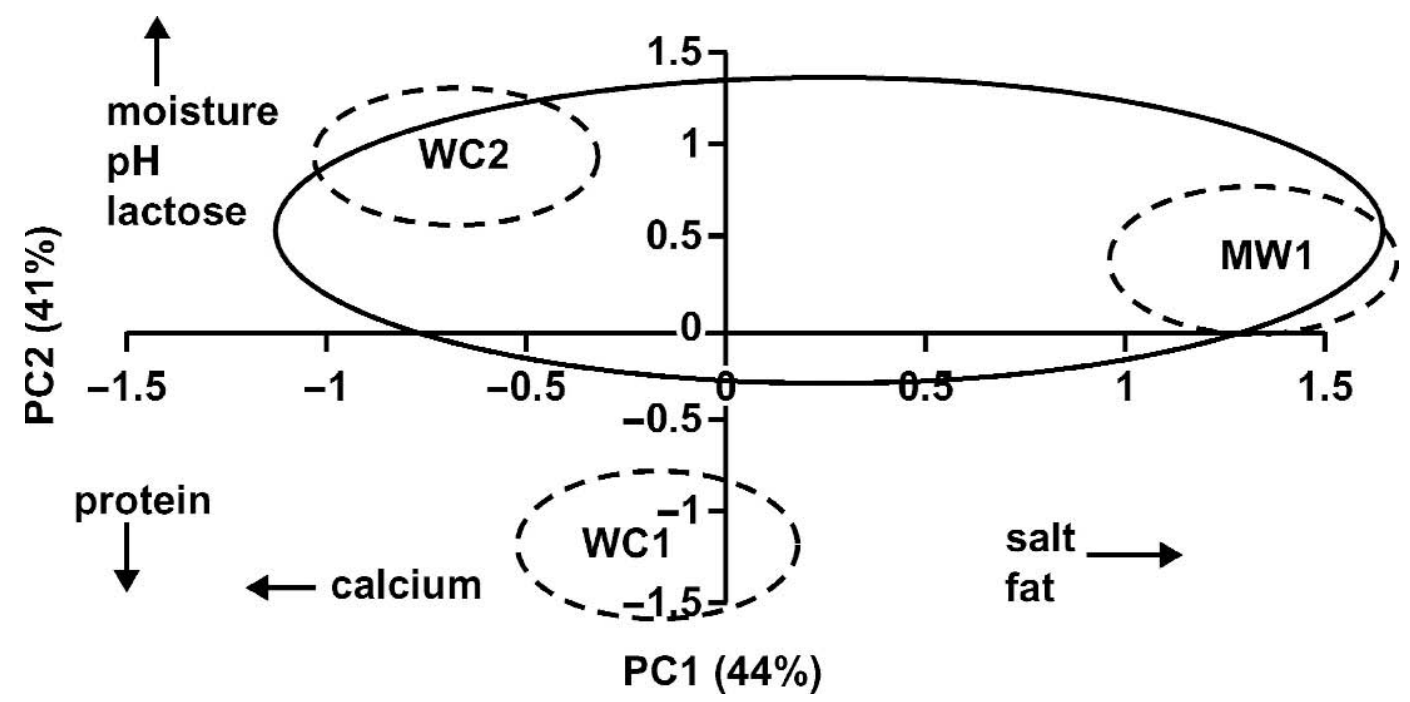

Figure 1. First 2 principal components (PC1, PC2) of compositional analysis of commercial whey. Processors (WC1, WC2, MW1) in same circle have no significant difference at $95 \%$ confidence interval. Bold line separated on PC2; dotted line separated on PC1. 
analyses, ANOVA with means separation was performed using SPSS version 11.0 (SPSS Inc., Chicago, IL) at $95 \%$ confidence. Differences between whey powders were recognized by principal component analysis. For the sensory data, 3-way ANOVA for each descriptor was performed using multivariate ANOVA using SAS version 8 (SAS Institute, Inc., Cary, NC). The factors storage time, panelist, and replication were taken into consideration. Based on the results of the ANOVA, simultaneous confidence interval for differences on the 5\% level were calculated using Tukey LSD.

\section{RESULTS AND DISCUSSION}

\section{Composition}

The compositional data of the whey powders is given in Table 2. Principal component analysis (Figure 1) demonstrated that the 3 samples were significantly different based on principal component 1 . Principal component 1 separates the samples based on calcium, salt, and fat. Samples MW1 and WC2 were significantly different from WC1 based on principal component 2. Principal component 2 separates the samples based on moisture, $\mathrm{pH}$, lactose, and protein.

\section{Rate of Brown Pigment Formation}

Rate constants were obtained for brown pigment formation assuming a zero-order rate relationship based on the work of Labuza and Saltmarch (1981) on kinetics of browning and protein quality loss in whey powders. Most parameters that influence browning were kept constant except for composition, coreactant level, history of the raw material, and presence of trace metals and other catalysts. Therefore, variation in the rate of brown pigment formation would likely be a result of one or a combination of these factors.

Rate constants at $21,35,45$, and $50^{\circ} \mathrm{C}$ were obtained from the plots of color units/g of solid vs. storage time (Figures 2A and 2B). The temperature dependence of browning was determined using the typical Arrhenius (Figure 2C) relationship to obtain activation energies $\left(\mathbf{E}_{\mathbf{a}}\right)$ and $\mathrm{Q}_{10}$ values (increase in reaction rate for a $10^{\circ} \mathrm{C}$ increase in temperature). The data presented in Figure 2 were based on sample MW1. The Arrhenius equation is derived from a plot of $\log \mathrm{k}$ vs. $1 / \mathrm{T}(\mathrm{K})$, whose slope $=-\mathrm{E}_{\mathrm{a}} / 2.303 \mathrm{R}$, where $\mathrm{k}=$ rate constant for deteriorative reaction at temperature $\mathrm{T}, \mathrm{E}_{\mathrm{a}}=$ activation energy $(\mathrm{kcal} / \mathrm{mol})$, and $\mathrm{R}$ (ideal gas constant) = $1.98722 \mathrm{cal} / \mathrm{K}$ per mol. The $\mathrm{Q}_{10}$ factor is defined as the rate of reaction a temperature $(\mathrm{T}+10)$ divided by the
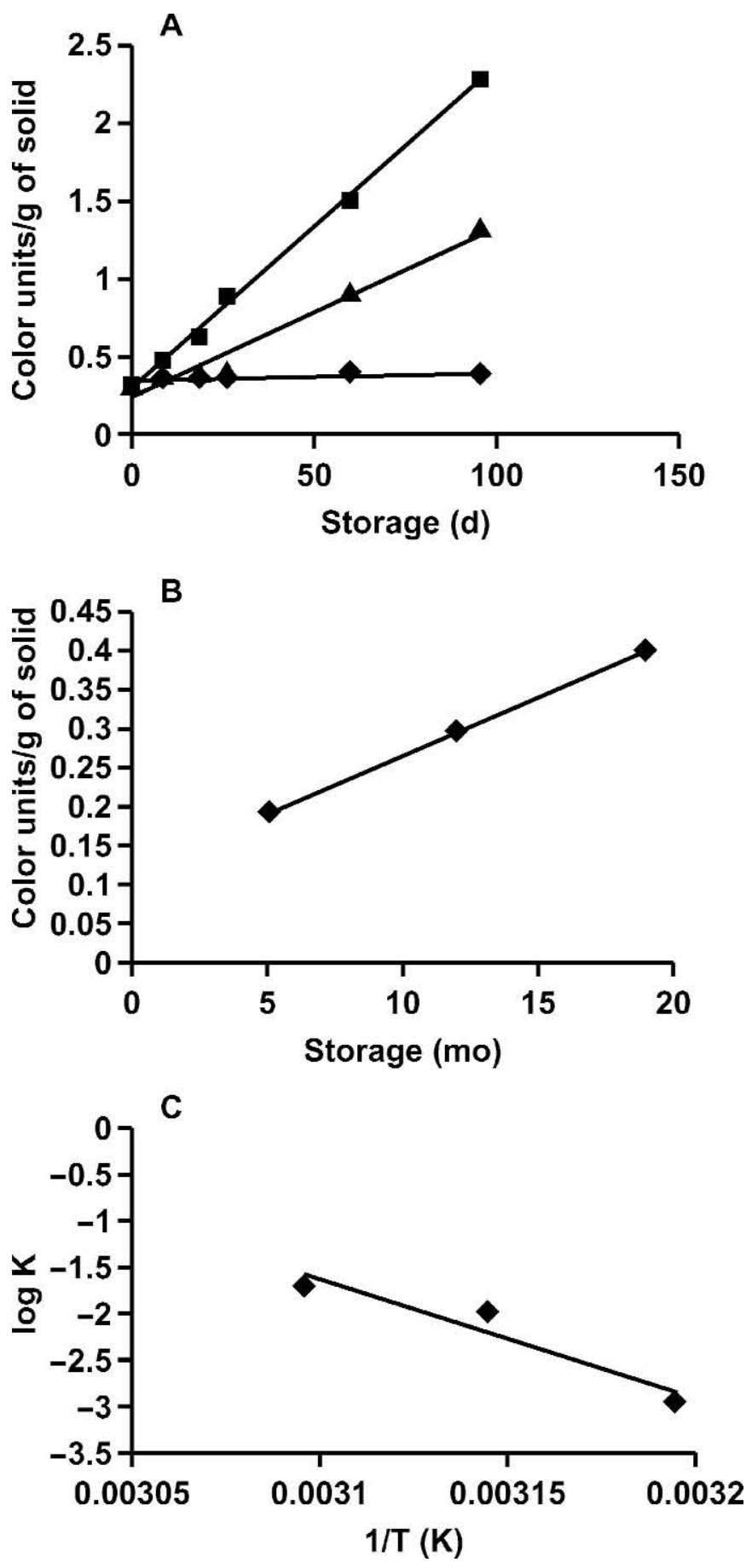

Figure 2. Plots for determining rate of brown pigment formation under accelerated shelf life testing (ASLT), ambient conditions and the Arrhenius plot for whey powder sample from Midwest. A. Rate of brown pigment formation for sweet whey powder stored at elevated temperatures: $35^{\circ} \mathrm{C}(\bullet), 45^{\circ} \mathrm{C}(\boldsymbol{\Delta})$, and $50^{\circ} \mathrm{C}(\boldsymbol{\square})$. B. Rate of brown pigment formation at $21^{\circ} \mathrm{C}, 35 \% \mathrm{RH}$. C. Arrhenius plot for the rate of brown pigment formation. 
Table 4. Rate of brown pigment formation $(\mathrm{k}), \mathrm{Q}_{10}$, and activation energy $\left(\mathrm{E}_{\mathrm{a}}\right)$ for 3 sweet whey powders (WC1, WC2, MW1).

\begin{tabular}{lcllll}
\hline Processor $^{1}$ & $\begin{array}{c}\text { Actual }^{2} \\
\mathrm{k} \times 10^{3}\end{array}$ & $\begin{array}{l}\text { Estimated }^{3} \\
\mathrm{k} \times 10^{3}\end{array}$ & $\begin{array}{l}\text { Estimated } \\
\mathrm{k} / \text { actual k }^{4}\end{array}$ & $\mathrm{Q}_{10}$ & $\mathrm{E}_{\mathrm{a}}{ }^{5}$ \\
\hline WC1 & 3.1 & 3.5 & 1.12 & 3.00 & 28.40 \\
WC2 & 8.0 & 39.2 & 4.90 & 1.77 & 15.872 \\
MW1 & 14.8 & 20.1 & 1.35 & 4.14 & 26.41 \\
\hline
\end{tabular}

${ }^{1} \mathrm{WC}=$ Processors from West coast; $\mathrm{MW}=$ processor from Midwest.

${ }^{2}$ Actual $\mathrm{k}$ was determined from whey powders stored at $21^{\circ} \mathrm{C}$ and $35 \% \mathrm{RH}$.

${ }^{3}$ Rate of brown pigment formation (k) determined from accelerated shelf-life testing.

${ }^{4}$ Factor by which the estimated value is bigger than the actual $\mathrm{k}$.

${ }^{5} \mathrm{In} \mathrm{kcal} / \mathrm{mol}$.

rate of reaction at temperature $(\mathrm{T})$. Color units/g of solid was calculated from the standard curve.

Plots of color units/g of solid vs. storage time for the 3 whey samples gave straight lines as supported by a high correlation to zero order, $\mathrm{R}^{2}$ between 0.82 and 1.00. Equations and respective $R^{2}$ values at the different temperatures for the various processors as determined from the graphs (Figure 2) are summarized in Table 3 and confirm that the Maillard reaction follows zero order in whey powder. Although only results from MW1 were plotted, other samples exhibited similar behavior.

The estimated values from accelerated testing of $\mathrm{k}$ at room temperature were determined by extrapolation from the Arrhenius plots of log k vs. 1/T(K) (Figure $2 \mathrm{C}$ ). The estimated $\mathrm{k}$ values were $1.12,4.90$, and 1.35 times bigger than the actual $\mathrm{k}$ values for $\mathrm{WC} 1, \mathrm{WC} 2$, and MW, respectively. Actual k values were obtained from samples stored at $21^{\circ} \mathrm{C}$ and $35 \% \mathrm{RH}$. Sample WC2 had the lowest $\mathrm{E}_{\mathrm{a}}$ and the highest initial $\mathrm{pH}$, which should result in increased Maillard reaction rate. However, $\mathrm{WC}_{2}$ had a $\mathrm{Q}_{10}$ of 1.77 , which is below the range of 2.0 to 8.0 reported for brown pigment formation for a number of food systems (Labuza and Saltmarch, 1981). Although WC2 was most prone to Maillard reactions, it had the smallest $\mathrm{Q}_{10}$ implying that for the same increase in temperature, the increase in rate of brown pigment formation was the smallest. One possible cause of the lower than expected rate of Maillard reaction in WC2 might be the presence of an additive that could inhibit or retard the Maillard reaction. The most commonly implicated Maillard reaction inhibitor is sulfur dioxide. No sulfite was detected in the sample (Table 2), but this does not exclude the possibility of sulfur dioxide addition, as it is not readily recovered following reaction (McWeeny, 1981)

The higher color units/g of solid in WC2 under high temperature storage could be due to its high mineral content; WC2 had the highest calcium content although the salt content was similar to WC1 (Table 2).
It is well known that certain salts and buffers have an accelerating effect on Maillard reactions in solution (Saunders and Jervis, 1966; Bell, 1997). Burin et al. (2000) reported an increased Maillard reaction with increased salt content in anhydrous systems. The salt content of MW1 was significantly higher than for the other samples, which may explain the higher level of browning for this sample when stored under normal storage conditions (Table 4).

Sample WC1 was the most stable whey powder with the highest $\mathrm{E}_{\mathrm{a}}$ and the lowest rate of deterioration as measured by the rate of Maillard reaction, $\mathrm{k}$ (Table 4). Activation energy values of 20 to $40 \mathrm{kcal} / \mathrm{mol}$ have been reported by Labuza and Saltmarch (1981) in food systems. Samples WC1 and MW1 fell within this range, unlike WC2. Sample WC1 also had the lowest free moisture content (Table 1). The higher free moisture contents in WC2 and MW1 likely contributed to their higher rates of brown pigment formation. Labuza and Saltmarch (1981) found that an increase in water content above the monolayer value dissolves and mobilizes reactant species for the Maillard reaction, hence increasing the reaction rate.

\section{Physicochemical and Microbiological Analyses}

Principal component analysis of the microbiological and physicochemical properties of sample MW1 stored under normal storage conditions (Figure 3) showed that Hunter Laboratory values L* (lightness-darkness parameter) and a* (redness-greenness parameter) provided optimal sensitivity for detecting changes in whey powders during storage. An increase in a* represents an increase in red; a decrease in $\mathrm{L}^{*}$ represents an increase in darkness (Hutchings, 1994). Sample WC1 did not change in $a^{*}$ parameter, whereas WC2 and MW1 gained in redness. All 3 samples darkened with storage (Table 5).

Storage time had a highly significant effect on moisture. During the 19-mo storage period, moisture content increased by $32 \%$ for MW1, $45 \%$ for $\mathrm{WC} 1$, and 


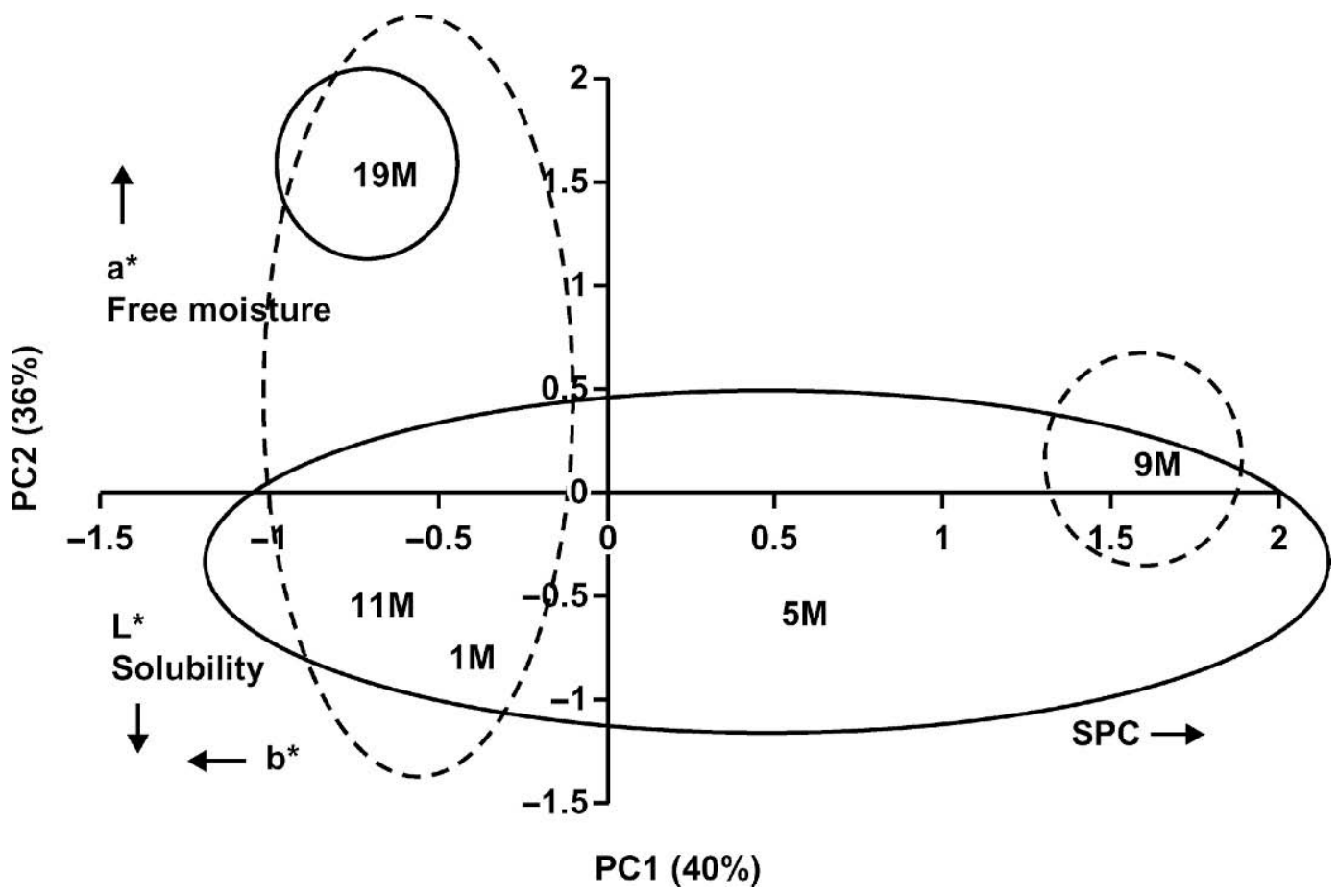

Figure 3. First 2 principal components (PC1, PC2) on physicochemical and microbiological data for Midwest whey processor (MW1). There was no significant difference in storage time in the same circle at $95 \%$ confidence interval. L* $=$ Hunter Lab lightness-darkness parameter; $\mathrm{a}^{*}=$ Hunter Lab red-green parameter; $\mathrm{b}^{*}=$ Hunter Lab blue-yellow parameter; SPC = standard plate count; $\mathrm{M}=$ mo of storage at $21^{\circ} \mathrm{C}$ and $35 \% \mathrm{RH}$. Bold line separated on PC2; dotted line separated on PC1.

Table 5. Microbiological and physicochemical properties of whey powder stored for up to 19 mo at $21^{\circ} \mathrm{C}$ and $35 \% \mathrm{RH}$.

\begin{tabular}{|c|c|c|c|c|c|c|c|c|c|c|c|}
\hline Processor $^{1}$ & $\begin{array}{c}\text { Storage } \\
\text { time }(\mathrm{mo})\end{array}$ & $\begin{array}{c}\mathrm{TA}^{2} \\
(\% \mathrm{LA})\end{array}$ & $\mathrm{pH}$ & $\begin{array}{r}\mathrm{SI}^{3} \\
(\mathrm{~mL})\end{array}$ & $\% \mathrm{MC}^{4}$ & $\mathrm{~L}^{*}$ & $a^{*}$ & $b^{*}$ & $\begin{array}{c}\mathrm{SPC}^{5} \\
(\mathrm{cfu} / \mathrm{g})\end{array}$ & $\begin{array}{l}\mathrm{MSC}^{6} \\
(\mathrm{cfu} / \mathrm{g})\end{array}$ & $\begin{array}{c}\mathrm{Y} \& \mathrm{M} / \\
\mathrm{Coli} \\
\text { (cfu/g) }\end{array}$ \\
\hline \multirow[t]{5}{*}{ WC1 } & 1 & $0.11^{\mathrm{a}}$ & $6.13^{b}$ & $<0.1^{\mathrm{a}}$ & $1.31^{\mathrm{b}}$ & $91.63^{\mathrm{e}}$ & $+1.11^{\mathrm{a}}$ & $+21.99^{\mathrm{ab}}$ & $<10$ & $\mathrm{ND}^{8}$ & $<10 /<10$ \\
\hline & 5 & $0.11^{\mathrm{a}}$ & $6.10^{\mathrm{b}}$ & $<0.1^{\mathrm{a}}$ & $1.32^{\mathrm{b}}$ & $91.15^{\mathrm{d}}$ & $+1.25^{\mathrm{a}}$ & $+22.01^{\mathrm{ab}}$ & $<10$ & ND & $<10 /<10$ \\
\hline & 9 & $0.12^{\mathrm{a}}$ & $6.12^{\mathrm{b}}$ & $0.11^{\mathrm{a}}$ & $1.34^{\mathrm{b}}$ & $90.92^{c}$ & $+1.22^{\mathrm{a}}$ & $+21.69^{\mathrm{a}}$ & $<10$ & ND & $<10 /<10$ \\
\hline & 10 & $0.10^{\mathrm{a}}$ & $5.97^{\mathrm{a}}$ & $0.12^{\mathrm{a}}$ & $1.14^{\mathrm{a}}$ & $90.81^{\mathrm{b}}$ & $+1.17^{\mathrm{a}}$ & $+22.12^{\mathrm{b}}$ & $<10$ & ND & $<10 /<10$ \\
\hline & 19 & $0.12^{\mathrm{a}}$ & $6.00^{\mathrm{a}}$ & $0.2^{\mathrm{b}}$ & $1.90^{\mathrm{c}}$ & $90.69^{\mathrm{a}}$ & $+1.27^{\mathrm{a}}$ & $+21.86^{\mathrm{ab}}$ & $<10$ & ND & $<10 /<10$ \\
\hline \multirow[t]{6}{*}{ WC2 } & 1 & $0.08^{\mathrm{a}}$ & $6.45^{\mathrm{e}}$ & $0.26^{\mathrm{b}}$ & $1.64^{\mathrm{a}}$ & $90.90^{\mathrm{d}}$ & $-0.59^{b}$ & $+22.02^{\mathrm{b}}$ & $400^{\mathrm{b}}$ & $70^{\mathrm{a}}$ & $<10 /<10$ \\
\hline & 4 & $0.08^{\mathrm{ab}}$ & $6.44^{\mathrm{e}}$ & $0.25^{\mathrm{b}}$ & $1.65^{\mathrm{a}}$ & $90.82^{\mathrm{d}}$ & $-0.72^{b}$ & $+21.94^{\mathrm{b}}$ & $200^{\mathrm{a}}$ & $85^{\mathrm{a}}$ & $<10 /<10$ \\
\hline & 5 & $0.09^{\mathrm{b}}$ & $6.31^{\mathrm{b}}$ & $0.25^{\mathrm{b}}$ & $1.61^{\mathrm{a}}$ & $90.42^{\mathrm{b}}$ & $-0.66^{\mathrm{b}}$ & $+22.84^{\mathrm{c}}$ & $260^{\mathrm{a}}$ & $90^{\mathrm{ab}}$ & $<10 /<1$ \\
\hline & 7 & $0.09^{\mathrm{ab}}$ & $6.4^{\mathrm{d}}$ & $0.25^{\mathrm{b}}$ & $1.66^{\mathrm{a}}$ & $90.67^{\mathrm{c}}$ & $-0.73^{\mathrm{b}}$ & $+22.87^{\mathrm{c}}$ & $230^{\mathrm{a}}$ & $150^{\mathrm{b}}$ & $<10 /<1$ \\
\hline & 10 & $0.10^{c}$ & $6.2^{\mathrm{a}}$ & $0.20^{\mathrm{a}}$ & $1.93^{b}$ & $90.66^{\mathrm{c}}$ & $-0.11^{\mathrm{a}}$ & $+20.57^{\mathrm{a}}$ & $150^{\mathrm{a}}$ & $90^{\mathrm{ab}}$ & $<10 /<10$ \\
\hline & 19 & $0.09^{b}$ & $6.35^{\mathrm{c}}$ & $0.20^{\mathrm{a}}$ & $2.04^{\mathrm{c}}$ & $90.15^{\mathrm{a}}$ & $-0.21^{\mathrm{c}}$ & $+22.55^{b c}$ & $220^{\mathrm{a}}$ & $85^{\mathrm{a}}$ & $<10 /<10$ \\
\hline \multirow[t]{5}{*}{ MW1 } & 1 & $0.12^{\mathrm{a}}$ & $6.18^{\mathrm{b}}$ & $0.3^{\mathrm{c}}$ & $1.80^{\mathrm{a}}$ & $91.38^{\mathrm{d}}$ & $-0.42^{\mathrm{a}}$ & $+22.89^{\mathrm{b}}$ & $1910^{c}$ & ND & $<10 /<10$ \\
\hline & 5 & $0.13^{\mathrm{a}}$ & $6.06^{\mathrm{a}}$ & $0.3^{\mathrm{c}}$ & $2.02^{\mathrm{ab}}$ & $91.22^{\mathrm{c}}$ & $-0.46^{\mathrm{a}}$ & $+22.50^{\mathrm{b}}$ & $2480^{\mathrm{d}}$ & ND & $<10 /<10$ \\
\hline & 9 & $0.15^{\mathrm{b}}$ & $6.15^{\mathrm{b}}$ & $0.28^{b}$ & $2.26^{\mathrm{bc}}$ & $91.35^{\mathrm{d}}$ & $-0.43^{\mathrm{a}}$ & $+21.75^{\mathrm{a}}$ & $4060^{\mathrm{e}}$ & ND & $<10 /<10$ \\
\hline & 11 & $0.12^{\mathrm{a}}$ & $6.08^{\mathrm{a}}$ & $0.27^{b}$ & $1.86^{\mathrm{a}}$ & $90.53^{b}$ & $-0.27^{\mathrm{b}}$ & $+24.34^{\mathrm{c}}$ & $1070^{\mathrm{b}}$ & ND & $<10 /<10$ \\
\hline & 19 & $0.12^{\mathrm{a}}$ & $6.09^{\mathrm{a}}$ & $0.24^{\mathrm{a}}$ & $2.37^{\mathrm{c}}$ & $89.80^{\mathrm{a}}$ & $-0.40^{\mathrm{c}}$ & $+24.31^{\mathrm{c}}$ & $180^{\mathrm{a}}$ & ND & $<10 /<10$ \\
\hline
\end{tabular}

${ }^{\mathrm{a}-\mathrm{c}}$ Means within columns with different letters are statistically different $(P<0.05)$.

${ }^{1} \mathrm{WC}=$ Processors from West coast; MW = processor from Midwest.

${ }^{2}$ Titratable acidity determined as \% lactic acid.

${ }^{3} \mathrm{SI}=$ Solubility index.

${ }^{4} \mathrm{MC}=$ Moisture content $(\%)$.

${ }^{5} \mathrm{SPC}=$ Standard plate count.

${ }^{6} \mathrm{MSC}=$ Mesophilic spore count.

${ }^{7} \mathrm{Y} \& \mathrm{M} / \mathrm{Coli}=$ Yeast, molds, and coliform bacteria.

${ }^{8} \mathrm{ND}=$ Not detected 
Table 6. Mean rating ${ }^{1}$ ( \pm standard deviation) for sensory descriptors tested of sweet whey powder (WC1, WC2, MW1) ${ }^{2}$ stored for up to 19 mo at $21^{\circ} \mathrm{C}$ and $35 \%$ RH.

\begin{tabular}{|c|c|c|c|c|c|c|c|c|c|c|c|c|c|c|}
\hline $\begin{array}{c}\text { Storage } \\
\text { time (mo) }\end{array}$ & $\begin{array}{l}\text { Sweet } \\
\text { aromatic } \\
\text { flavor }\end{array}$ & $\begin{array}{l}\text { Caramelized } \\
\text { flavor }\end{array}$ & $\begin{array}{l}\text { Cooked } \\
\text { flavor }\end{array}$ & $\begin{array}{l}\text { Cardboard } \\
\text { flavor }\end{array}$ & $\begin{array}{l}\text { Oxidized } \\
\text { flavor }\end{array}$ & Barny & $\begin{array}{l}\text { Sweet } \\
\text { aromatic } \\
\text { aroma }\end{array}$ & $\begin{array}{l}\text { Caramelized } \\
\text { aroma }\end{array}$ & $\begin{array}{l}\text { Cooked } \\
\text { aroma }\end{array}$ & $\begin{array}{l}\text { Cardboard } \\
\text { aroma }\end{array}$ & $\begin{array}{l}\text { Oxidized } \\
\text { aroma }\end{array}$ & $\begin{array}{l}\text { Sweet } \\
\text { flavor }\end{array}$ & $\begin{array}{l}\text { Sour } \\
\text { flavor }\end{array}$ & $\begin{array}{l}\text { Salty } \\
\text { flavor }\end{array}$ \\
\hline \multicolumn{15}{|l|}{ WC1 } \\
\hline 1 & $\begin{array}{c}1.41 \\
(1.53)\end{array}$ & $\begin{array}{c}2.41 \\
(1.59)\end{array}$ & $\begin{array}{l}3.92 \\
(1.75)\end{array}$ & $\begin{array}{c}1.82 \\
(1.54)\end{array}$ & $\begin{array}{c}1.21 \\
(1.30)\end{array}$ & $\begin{array}{l}0.82 \\
(1.36)\end{array}$ & $\begin{array}{l}1.46 \\
(1.52)\end{array}$ & $\begin{array}{c}2.72 \\
(1.60)\end{array}$ & $\begin{array}{c}4.38 \\
(1.98)\end{array}$ & $\begin{array}{l}1.41 \\
(1.23)\end{array}$ & $\begin{array}{c}1.21 \\
(1.26)\end{array}$ & $\begin{array}{l}4.10 \\
(2.06)\end{array}$ & $\begin{array}{l}1.59 \\
(1.74)\end{array}$ & $\begin{array}{c}2.59 \\
(2.42)\end{array}$ \\
\hline 5 & $\begin{array}{l}1.44 \\
(1.41)\end{array}$ & $\begin{array}{c}2.72 \\
(1.54)\end{array}$ & $\begin{array}{c}4.03 \\
(1.89)\end{array}$ & $\begin{array}{c}1.51 \\
(1.41)\end{array}$ & $\begin{array}{c}1.13 \\
(1.26)\end{array}$ & $\begin{array}{l}0.95 \\
(1.17)\end{array}$ & $\begin{array}{c}1.51 \\
(1.59)\end{array}$ & $\begin{array}{c}3.03 \\
(1.76)\end{array}$ & $\begin{array}{l}4.46 \\
(1.78)\end{array}$ & $\begin{array}{l}1.56 \\
(1.29)\end{array}$ & $\begin{array}{c}1.23 \\
(1.22)\end{array}$ & $\begin{array}{c}4.31 \\
(1.79)\end{array}$ & $\begin{array}{l}1.49 \\
(1.41)\end{array}$ & $\begin{array}{c}2.72 \\
(2.46)\end{array}$ \\
\hline 9 & $\begin{array}{c}1.18 \\
(1.28)\end{array}$ & $\begin{array}{c}2.72 \\
(1.61)\end{array}$ & $\begin{array}{c}4.15 \\
(2.20)\end{array}$ & $\begin{array}{c}1.59 \\
(1.55)\end{array}$ & $\begin{array}{c}1.10 \\
(1.14)\end{array}$ & $\begin{array}{c}1.21 \\
(1.36)\end{array}$ & $\begin{array}{c}1.38 \\
(1.33)\end{array}$ & $\begin{array}{c}3.05 \\
(1.86)\end{array}$ & $\begin{array}{c}4.36 \\
(2.01)\end{array}$ & $\begin{array}{c}1.62 \\
(1.27)\end{array}$ & $\begin{array}{c}1.54 \\
(1.65)\end{array}$ & $\begin{array}{c}3.82 \\
(1.80)\end{array}$ & $\begin{array}{c}1.26 \\
(1.48)\end{array}$ & $\begin{array}{c}2.72 \\
(2.32)\end{array}$ \\
\hline 12 & $\begin{array}{c}1.26 \\
(1.29)\end{array}$ & $\begin{array}{l}2.54 \\
(1.92)\end{array}$ & $\begin{array}{l}3.90 \\
(1.20)\end{array}$ & $\begin{array}{c}1.92 \\
(1.58)\end{array}$ & $\begin{array}{c}1.10 \\
(1.94)\end{array}$ & $\begin{array}{l}1.36 \\
(1.87)\end{array}$ & $\begin{array}{c}1.41 \\
(1.33)\end{array}$ & $\begin{array}{c}2.92 \\
(1.80)\end{array}$ & $\begin{array}{l}4.36 \\
(1.83)\end{array}$ & $\begin{array}{l}1.79 \\
(1.30)\end{array}$ & $\begin{array}{c}1.31 \\
(1.54)\end{array}$ & $\begin{array}{c}4.31 \\
(1.95)\end{array}$ & $\begin{array}{c}1.44 \\
(1.52)\end{array}$ & $\begin{array}{c}2.49 \\
(2.30)\end{array}$ \\
\hline 19 & $\begin{array}{c}1.38 \\
(1.39)\end{array}$ & $\begin{array}{l}2.44 \\
(1.85)\end{array}$ & $\begin{array}{l}4.10 \\
(2.44)\end{array}$ & $\begin{array}{c}1.87 \\
(1.61)\end{array}$ & $\begin{array}{c}1.56 \\
(1.31)\end{array}$ & $\begin{array}{l}1.59 \\
(2.15)\end{array}$ & $\begin{array}{l}1.36 \\
(1.42)\end{array}$ & $\begin{array}{l}2.49 \\
(2.00)\end{array}$ & $\begin{array}{l}4.21 \\
(2.52)\end{array}$ & $\begin{array}{c}1.79 \\
(1.13)\end{array}$ & $\begin{array}{l}1.90 \\
(1.73)\end{array}$ & $\begin{array}{l}3.79 \\
(1.542)\end{array}$ & $\begin{array}{c}1.41 \\
(1.52)\end{array}$ & $\begin{array}{c}2.56 \\
(2.22)\end{array}$ \\
\hline \multicolumn{15}{|l|}{ WC2 } \\
\hline 1 & $\begin{array}{c}1.23 \\
(1.35)\end{array}$ & $\begin{array}{c}2.67 \\
(1.87)\end{array}$ & $\begin{array}{c}3.77 \\
(1.97)\end{array}$ & $\begin{array}{c}1.92 \\
(1.69)\end{array}$ & $\begin{array}{c}1.74 \\
(1.63)\end{array}$ & $\begin{array}{c}1.62 \\
(1.81)\end{array}$ & $\begin{array}{c}1.59 \\
(1.41)\end{array}$ & $\begin{array}{c}2.77 \\
(1.56)\end{array}$ & $\begin{array}{c}4.28 \\
(1.91)\end{array}$ & $\begin{array}{c}1.95 \\
(1.54)\end{array}$ & $\begin{array}{c}1.41 \\
(1.71)\end{array}$ & $\begin{array}{c}4.82 \\
(1.89)\end{array}$ & $\begin{array}{c}1.15 \\
(1.25)\end{array}$ & $\begin{array}{c}2.21 \\
(1.92)\end{array}$ \\
\hline 5 & $\begin{array}{c}1.31 \\
(1.32)\end{array}$ & $\begin{array}{c}2.67 \\
(2.04)\end{array}$ & $\begin{array}{c}3.97 \\
(2.18)\end{array}$ & $\begin{array}{c}2.10 \\
(1.55)\end{array}$ & $\begin{array}{c}1.44 \\
(1.41)\end{array}$ & $\begin{array}{c}1.41 \\
(1.48)\end{array}$ & $\begin{array}{c}1.54 \\
(1.54)\end{array}$ & $\begin{array}{c}2.85 \\
(1.73)\end{array}$ & $\begin{array}{c}4.15 \\
(2.05)\end{array}$ & $\begin{array}{c}1.77 \\
(1.56)\end{array}$ & $\begin{array}{c}1.44 \\
(1.59)\end{array}$ & $\begin{array}{c}4.79 \\
(1.70)\end{array}$ & $\begin{array}{c}0.90 \\
(1.07)\end{array}$ & $\begin{array}{c}2.33 \\
(1.98)\end{array}$ \\
\hline 10 & $\begin{array}{c}0.97 \\
(1.11)\end{array}$ & $\begin{array}{l}2.51 \\
(2.02)\end{array}$ & $\begin{array}{l}4.00 \\
(2.25)\end{array}$ & $\begin{array}{l}2.15 \\
(1.46)\end{array}$ & $\begin{array}{l}1.85 \\
(1.48)\end{array}$ & $\begin{array}{l}1.49 \\
(1.45)\end{array}$ & $\begin{array}{c}1.31 \\
(1.10)\end{array}$ & $\begin{array}{l}2.87 \\
(2.31)\end{array}$ & $\begin{array}{l}4.33 \\
(2.09)\end{array}$ & $\begin{array}{c}1.69 \\
(1.26)\end{array}$ & $\begin{array}{l}1.97 \\
(1.61)\end{array}$ & $\begin{array}{c}3.87 \\
(1.56)\end{array}$ & $\begin{array}{l}1.23 \\
(1.40)\end{array}$ & $\begin{array}{c}2.74 \\
(2.12)\end{array}$ \\
\hline 12 & $\begin{array}{c}0.97 \\
(1.20)\end{array}$ & $\begin{array}{c}2.74 \\
(1.93)\end{array}$ & $\begin{array}{c}3.74 \\
(1.59)\end{array}$ & $\begin{array}{c}2.44 \\
(1.20)\end{array}$ & $\begin{array}{c}1.85 \\
(1.51)\end{array}$ & $\begin{array}{c}2.00 \\
(1.59)\end{array}$ & $\begin{array}{c}1.31 \\
(1.10)\end{array}$ & $\begin{array}{c}3.05 \\
(1.79)\end{array}$ & $\begin{array}{c}3.95 \\
(1.81)\end{array}$ & $\begin{array}{c}2.00 \\
(1.34)\end{array}$ & $\begin{array}{c}2.15 \\
(1.91)\end{array}$ & $\begin{array}{c}4.23 \\
(1.98)\end{array}$ & $\begin{array}{c}0.90 \\
(1.07)\end{array}$ & $\begin{array}{c}2.31 \\
(1.91)\end{array}$ \\
\hline MW1 & $\begin{array}{l}1.00 \\
(1.17)\end{array}$ & $\begin{array}{c}2.72 \\
(1.99)\end{array}$ & $\begin{array}{c}4.03 \\
(2.67)\end{array}$ & $\begin{array}{c}2.38 \\
(1.70)\end{array}$ & $\begin{array}{c}1.97 \\
(1.83)\end{array}$ & $\begin{array}{l}1.85 \\
(1.73)\end{array}$ & $\begin{array}{c}1.46 \\
(1.43)\end{array}$ & $\begin{array}{l}2.72 \\
(1.959)\end{array}$ & $\begin{array}{l}4.16 \\
(2.746)\end{array}$ & $\begin{array}{c}1.95 \\
(1.30)\end{array}$ & $\begin{array}{c}1.67 \\
(1.60)\end{array}$ & $\begin{array}{c}4.54 \\
(2.10)\end{array}$ & $\begin{array}{l}1.00 \\
(1.34)\end{array}$ & $\begin{array}{c}2.26 \\
(1.76)\end{array}$ \\
\hline 1 & $\begin{array}{c}1.10 \\
(1.19)\end{array}$ & $\begin{array}{c}2.90 \\
(2.32)\end{array}$ & $\begin{array}{c}3.95 \\
(2.08)\end{array}$ & $\begin{array}{c}1.97 \\
(1.40)\end{array}$ & $\begin{array}{c}1.64 \\
(1.46)\end{array}$ & $\begin{array}{c}1.64 \\
(1.56)\end{array}$ & $\begin{array}{c}1.10 \\
(1.12)\end{array}$ & $\begin{array}{c}3.10 \\
(2.25)\end{array}$ & $\begin{array}{c}4.18 \\
(2.38)\end{array}$ & $\begin{array}{c}1.79 \\
(1.40)\end{array}$ & $\begin{array}{c}1.72 \\
(1.65)\end{array}$ & $\begin{array}{c}3.54 \\
(1.55)\end{array}$ & $\begin{array}{c}1.41 \\
(1.48)\end{array}$ & $\begin{array}{c}2.64 \\
(2.40)\end{array}$ \\
\hline 5 & $\begin{array}{c}1.23 \\
(1.08)\end{array}$ & $\begin{array}{c}2.08 \\
(1.65)\end{array}$ & $\begin{array}{l}3.87 \\
(2.14)\end{array}$ & $\begin{array}{c}2.31 \\
(2.12)\end{array}$ & $\begin{array}{c}1.64 \\
(1.63)\end{array}$ & $\begin{array}{l}1.44 \\
(1.35)\end{array}$ & $\begin{array}{c}1.23 \\
(1.14)\end{array}$ & $\begin{array}{l}2.44 \\
(2.14)\end{array}$ & $\begin{array}{c}4.28 \\
(2.20)\end{array}$ & $\begin{array}{l}2.03 \\
(1.530)\end{array}$ & $\begin{array}{c}1.74 \\
(1.67)\end{array}$ & $\begin{array}{c}3.15 \\
(1.48)\end{array}$ & $\begin{array}{c}1.69 \\
(1.95)\end{array}$ & $\begin{array}{c}3.46 \\
(2.60)\end{array}$ \\
\hline 9 & $\begin{array}{c}0.92 \\
(1.13)\end{array}$ & $\begin{array}{l}3.05 \\
(2.13)\end{array}$ & $\begin{array}{l}4.10 \\
(1.90)\end{array}$ & $\begin{array}{l}2.49 \\
(1.54)\end{array}$ & $\begin{array}{l}1.69 \\
(1.44)\end{array}$ & $\begin{array}{l}1.13 \\
(1.32)\end{array}$ & $\begin{array}{l}1.03 \\
(1.04)\end{array}$ & $\begin{array}{l}2.92 \\
(2.03)\end{array}$ & $\begin{array}{c}3.97 \\
(1.91)\end{array}$ & $\begin{array}{l}2.28 \\
(1.45)\end{array}$ & $\begin{array}{c}1.64 \\
(1.60)\end{array}$ & $\begin{array}{c}3.51 \\
(1.67)\end{array}$ & $\begin{array}{l}2.15 \\
(2.38)\end{array}$ & $\begin{array}{c}3.53 \\
(2.69)\end{array}$ \\
\hline 12 & $\begin{array}{c}1.21 \\
(1.49)\end{array}$ & $\begin{array}{c}2.56 \\
(1.92)\end{array}$ & $\begin{array}{c}3.85 \\
(2.28)\end{array}$ & $\begin{array}{c}2.31 \\
(1.85)\end{array}$ & $\begin{array}{c}1.49 \\
(1.34)\end{array}$ & $\begin{array}{c}1.59 \\
(1.48)\end{array}$ & $\begin{array}{c}1.03 \\
(1.11)\end{array}$ & $\begin{array}{c}3.03 \\
(1.94)\end{array}$ & $\begin{array}{c}4.15 \\
(2.37)\end{array}$ & $\begin{array}{c}2.00 \\
(1.40)\end{array}$ & $\begin{array}{c}1.54 \\
(1.67)\end{array}$ & $\begin{array}{c}3.72 \\
(1.64)\end{array}$ & $\begin{array}{c}1.33 \\
(1.56)\end{array}$ & $\begin{array}{c}2.67 \\
(2.42)\end{array}$ \\
\hline 19 & $\begin{array}{c}1.18 \\
(1.10)\end{array}$ & $\begin{array}{l}3.08 \\
(2.10)\end{array}$ & $\begin{array}{c}4.11 \\
(2.18)\end{array}$ & $\begin{array}{c}2.62 \\
(1.89)\end{array}$ & $\begin{array}{c}1.77 \\
(1.53)\end{array}$ & $\begin{array}{l}1.18 \\
(1.17)\end{array}$ & $\begin{array}{l}1.10 \\
(1.07)\end{array}$ & $\begin{array}{l}3.18 \\
(2.08)\end{array}$ & $\begin{array}{c}4.38 \\
(1.84)\end{array}$ & $\begin{array}{c}2.21 \\
(1.26)\end{array}$ & $\begin{array}{l}1.59 \\
(1.55)\end{array}$ & $\begin{array}{c}3.85 \\
(1.58)\end{array}$ & $\begin{array}{c}1.38 \\
(1.53)\end{array}$ & $\begin{array}{c}2.79 \\
(2.51)\end{array}$ \\
\hline
\end{tabular}

${ }^{1}$ Mean of duplicate testing by 13 panelists; rating scale was a 15 -point scale, where $3=$ slight, and 7 = moderate.

${ }^{2} \mathrm{WC}=$ Processors from West coast; MW = processor from Midwest. 
$24 \%$ for WC2. Variations in moisture gain might be attributed to differences in water vapor transmission rate of the packaging material and to differences in hygroscopicity. Furthermore, differences in the gain in free moisture could be a result of the lactose crystal formed as bound water can be released during the transformation among amorphous and crystal lactose as well as the different lactose crystalline forms. A decreasing trend in $\mathrm{pH}$ was observed for all 3 samples. Decreases in whey $\mathrm{pH}$ as browning progresses were reported by Pilar Buera et al. (1990). Other causes for variation in deterioration rate of the whey powders might be related to differences in processing. No information was available regarding differences in processing parameters at the 3 manufacturing plants. Standard plate count decreased during storage for WC2 and MW1. Sample MW1 exhibited a 10-fold decrease, and WC2 had a 2 -fold decrease (Table 5). However, there was no significant change in the mesophilic spore count with storage for WC2, the only sample that contained mesophilic spores. The microbiological quality of WC1 was excellent, as no standard plate count or mesophilic spore count was detected. No yeast, molds, or coliform bacteria were detected in any of the samples.

\section{Sensory Evaluation}

Even though the sensory panel was highly trained, no significant differences were found in odor and flavor of the whey powders during 19 mo of storage. The mean rating and standard deviation for each of the descriptors tested are given in Table 6. The Maillard reaction has been reported to lead to flavor and aroma changes during storage. However, in this study, even the most rapidly deteriorating whey powder, as determined by the Maillard reaction, still had flavor and aroma perceived to be similar to that after $1 \mathrm{mo}$ of storage.

\section{CONCLUSION}

Our data suggest that whey powder has a shelf life longer than $12 \mathrm{mo}$, which is the typical shelf life reported by commercial suppliers. The deterioration rates of the sweet whey powders from the 3 processors were different. The sample with the fastest rate of deterioration, as determined by the Maillard reaction, was found to deteriorate the fastest as determined by the physicochemical parameter (Hunter Laboratory color parameter $\left.\mathrm{L}^{*}\right)$. However, the flavor and aroma of all whey powder samples remained constant. Although the Maillard reaction plays a major role in determining the rate of deterioration of whey powders at elevated temperatures, the rate at ambient conditions for the 3 samples was too low to cause any significant difference during storage up to $19 \mathrm{mo}$. Because free moisture content changed significantly with storage at ambient temperature, parameters related to moisture content, such as hygroscopicity and caking, should be explored in shelf-life studies of whey powder. It appears likely that whey powders deteriorate because of loss of functional properties such as flowability and dispersibility before any changes in taste and aroma are observed.

\section{ACKNOWLEDGMENTS}

Financial support was provided by Tillamook County Creamery Association, and the Eckelman Foundation.

\section{REFERENCES}

American Dairy Products Institute. 1991. Pages 7-19 in Whey and Whey Products: Definitions, Composition, Standard Methods of Analysis. Bulletin W-16. American Dairy Products Inst., Chicago, IL.

AOAC. 1995. Official Methods of Analysis. 16th ed. Association of Official Analytical Chemists International, Gaithersburg, MD.

AOAC. 2000. Official Methods of Analysis. 17th ed. Association of Official Analytical Chemists International, Gaithersburg, MD.

A/S Niro Atomizer. 1978. Determination of moisture. Pages 10-11 in Analytical Methods for Dry Milk Products. 4th ed. I. Haugaard Sorensen, J. Krag, J. Piecky, and V. Westergaard, ed. De Forenede Trykerier A/S, Copenhagen, Denmark.

Bell, L. N. 1997. Maillard reaction as influenced by buffer type and concentration. Food Chem. 59:143-147.

Burin, L., K. Jouppila, Y. Roos, J. Kansikas, and M. Buera. 2000. Color formation in dehydrated modified whey powder systems as affected by compression and $\mathrm{T}_{\mathrm{g}}$. J. Agric. Food Chem. 48:5263-5268.

Cämmerer, B., B. L. Wedzicha, and L. W. Kroh. 1999. Nonenzymatic browning reactions of retro-adol degradation products of carbohydrates. Eur. Food Res. Technol. 209:261-265.

Choi, R. P., C. M. O'Malley, and B. W. Fairbanks. 1949. A proposed method for the determination of color of dry products of milk. J. Dairy Sci. 32:580-586.

del Pilar Buera, M., J. Chirife, and S. L. Resnik. 1990. Nonenzymatic nonoxidative browning in hydrolyzed shelf-stable concentrated cheese whey. J. Food Sci. 55:697-700.

Ford, J. E., R. F. Hurrel, and P. A. Finot. 1983. Storage of milk powders under adverse conditions. 2. Influence of the content of water-soluble vitamins. Br. J. Nutr. 49:355-364.

Franzen, K., R. K. Singh, and M. R. Okos. 1990. Kinetics of nonenzymatic browning in dried skim milk. J. Food Eng. 11:225-239.

Hutchings, J. B. 1994. Page 221 in Instrumental Specification, Food Color and Appearance. J. B. Hutchings, ed. Blackie Academic \& Professional, Glasgow, UK.

Kamath, A., R. Ravi, and D. Rajalakshmi. 1999. Sensory profiling and positioning of commercial samples of milk powder. J. Sens. Stud. 14:303-319.

Karagül-Yüceer, Y., M. Drake, and K. R. Cadwallader. 2001. Aroma active components of nonfat dry milk. J. Agric. Food Chem. 49:2948-2953.

Kim, M., M. Saltmarch, and T. P. Labuza. 1981. Nonenzymatic browning of hygroscopic whey powders in open versus sealed pouches. J. Food Process. Preserv. 5:49-57. 
Labuza, T. P., and M. Saltmarch. 1981. Kinetics of browning and protein quality loss in whey powders during steady state and non steady state storage conditions. J. Food Sci. 47:92-96.

Lawless, H. T., and H. Heymann. 1999. Pages 358-362 in Sensory Evaluation of Food, Principles and Practices. Aspen Publishers, Inc., Frederick, MD.

McWeeny, D. J. 1981. Sulfur dioxide and the Maillard reaction in food. Prog. Food Nutr. Sci. 5:395-404.

Nielsen, B. R., H. Stapelfeldt, and L. H. Skibsted. 1997. Early prediction of the shelf-life of medium-heat whole milk powders using stepwise multiple regression and principal component analysis. Int. Dairy J. 7:341-348.

Presa-Owens, S., M. López-Sabater, and M. Rivero-Urgell. 1995. Shelf-life prediction of an infant formula using an accelerated stability test (Rancimat). J. Agric. Food Chem. 43:2879-2882.

Richardson, G. H. 1985. Standard Methods for the Examination of Dairy Products. 15th ed. American Public Health Association, Washington, DC.
Saltmarch, M., and T. Labuza. 1980. Influence of relative humidity on the physicochemical state of lactose in spray-dried sweet whey powders. J. Food Sci. 45:1231-1236.

Saltmarch, M., and T. P. Labuza. 1981. SEM investigation of the effect of lactose crystallization on the storage properties of spray dried whey. Scan. Electron Microsc. 3:659-665.

Saunders, J., and F. Jervis. 1966. The role of buffer salts in nonenzymatic browning. J. Sci. Food Agric. 17:245-249.

Stone, H., and J. L. Sidel. 1993. Sensory evaluation practices. Academic Press, Inc., Boston, MA.

Villota, R., and J. G. Hawkes. 1983. Effect of processing on kinetics of nutrients and organoleptic changes in foods. Paper presented at the Winter Meeting of the Am. Soc. Agric Engr., St. Joseph, MI.

Waletzko, P., and T. P. Labuza. 1976. Accelerated shelf life testing of an intermediate moisture food in air and in an oxygen-free atmosphere. J. Food Sci. 41:1338-1344. 